\title{
Maternal and neonatal trauma following operative vaginal delivery
}

\author{
Giulia M. Muraca PhD MPH, Amélie Boutin PhD, Neda Razaz PhD MPH, Sarka Lisonkova MD PhD, Sid John MSc, \\ Joseph Y. Ting MBBS MPH, Heather Scott MD, Michael S. Kramer MD, KS Joseph MD PhD
}

Cite as: CMAJ 2022 January 10;194:E1-12. doi: 10.1503/cmaj.210841

\begin{abstract}
Background: Operative vaginal delivery (OVD) is considered safe if carried out by trained personnel. However, opportunities for training in OVD have declined and, given these shifts in practice, the safety of OVD is unknown. We estimated incidence rates of trauma following OVD in Canada, and quantified variation in trauma rates by instrument, region, level of obstetric care and institutional OVD volume.
\end{abstract}

Methods: We conducted a cohort study of all singleton, term deliveries in Canada between April 2013 and March 2019, excluding Quebec. Our main outcome measures were maternal trauma (e.g., obstetric anal sphincter injury, high vaginal lacerations) and neonatal trauma (e.g., subgaleal hemorrhage, brachial plexus injury). We calculated adjusted and stabilized rates of trauma using mixed-effects logistic regression.

Results: Of 1326191 deliveries, 38500 (2.9\%) were attempted forceps deliveries and 110987 (8.4\%) were attempted vacuum deliveries. The maternal trauma rate following forceps delivery was $25.3 \%$ (95\% confidence interval [Cl] $24.8 \%-25.7 \%$ ) and the neonatal trauma rate was $9.6(95 \% \mathrm{Cl} 8.6-10.6)$ per 1000 live births. Maternal and neonatal trauma rates following vacuum delivery were $13.2 \%(95 \% \mathrm{Cl} 13.0 \%-13.4 \%)$ and 9.6 (95\% Cl 9.0-10.2) per 1000 live births, respectively. Maternal trauma rates remained higher with forceps than with vacuum after adjustment for confounders (adjusted rate ratio 1.70, 95\% $\mathrm{Cl} 1.65-1.75)$ and varied by region, but not by level of obstetric care.

Interpretation: In Canada, rates of trauma following OVD are higher than previously reported, irrespective of region, level of obstetric care and volume of OVD among hospitals. These results support a reassessment of OVD safety in Canada.

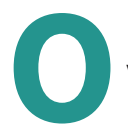

perative vaginal delivery (OVD) refers to forceps- or vacuum-assisted delivery used in the second stage of labour to facilitate vaginal birth when labour is arrested, to expedite delivery when there is imminent risk to the fetus or to avoid exertion for people with conditions that contraindicate pushing. ${ }^{1}$ The choice of forceps or vacuum application is based on factors such as the presence of marked caput or moulding, access to epidural anesthesia, safety of expulsive efforts, gestational age, fetal presentation, and operator and patient preference. ${ }^{2,3}$

In the second stage of labour, OVDs are alternatives to cesarean delivery, which can be challenging and result in serious maternal and perinatal morbidity. ${ }^{3}$ Although no randomized controlled trials have compared outcomes following OVD and cesarean delivery, ${ }^{4,5}$ recent observational studies in high-income countries have found that cesarean delivery in the second stage of labour is associated with higher rates of maternal infection and neonatal respiratory morbidity compared with OVD..$^{6-9}$ However,
OVDs are associated with important maternal and neonatal complications, most notably, severe maternal and neonatal trauma. ${ }^{5-9}$ Maternity care providers and pregnant people in their care are thus tasked with weighing the trauma risks of OVD with the surgical risks of cesarean delivery, often when delivery is urgent.

In recent years, OVD has accounted for $10 \%-15 \%$ of deliveries in Canada, ${ }^{10}$ Australia ${ }^{11}$ and the United Kingdom, ${ }^{12}$ where guidelines affirm the safety of OVD when performed appropriately by trained personnel. ${ }^{12-14}$ However, the risk associated with OVD is heavily dependent on the health provider's expertise, and the declining use of OVD (in favour of cesarean delivery) has reduced opportunities for acquiring proficiency in performing these deliveries, especially with forceps. ${ }^{10,15,16}$ As a result, OVD is under scrutiny in the face of reports of rising rates of maternal and neonatal trauma with OVD and of concerns regarding the relative safety of forceps versus vacuum. ${ }^{17-19}$

An evaluation of maternal and neonatal trauma following OVD is necessary to ensure that health care providers, policy-makers 
and pregnant people are informed regarding the risks of OVD typically experienced in routine obstetric practice, as opposed to those encountered in ideal conditions. Further, although enhanced training in OVD has been deemed urgent, ${ }^{3,12,16}$ little information is available to guide decisions on which centres in Canada are best suited to lead such training initiatives. ${ }^{20,21}$ Thus, we aimed to describe the incidence of maternal and neonatal trauma following OVD in Canada and to quantify the variability in trauma rates by instrument, region, level of obstetric care and institutional OVD volume.

\section{Methods}

\section{Study design and population}

We conducted a cohort study of deliveries in Canada between April 2013 and March 2019, excluding Quebec. We included all singleton, term ( $\geq 37$ weeks), in-hospital deliveries to pregnant people without a previous cesarean delivery that resulted in a live birth or stillbirth.

\section{Data sources}

We obtained data about hospital deliveries from the Canadian Institute for Health Information's (CIHI) Discharge Abstract Database, which contains information on $98 \%$ of hospital deliveries in Canada, excluding those in Quebec. ${ }^{22}$ Trained health records personnel abstract information from the databases using standardized definitions, and data consistency and accuracy are ensured through routine quality assurance checks.

Maternal, fetal and neonatal information in the database includes details regarding medical history, maternal characteristics, labour and delivery, neonatal condition, diagnoses and interventions. Diagnoses are coded using the International Classification of Diseases, 10th revision ${ }^{23}$ (ICD-10-CA), and interventions are coded using the Canadian Classification of Health Interventions (Appendix 1, Table S1, available at www.cmaj.ca/lookup/ doi/10.1503/cmaj.210841/tab-related-content). ${ }^{24}$ The accuracy of the perinatal information in the databases has been validated in previous studies (Appendix 1, Table S2). ${ }^{25-27}$

\section{Outcomes}

The primary outcomes were composite maternal trauma and composite neonatal trauma. We quantified maternal trauma rates among all deliveries, and quantified neonatal trauma rates for live births without a congenital malformation. Maternal trauma included obstetric anal sphincter injury (OASI), defined as third- or fourth-degree perineal tears; cervical or high vaginal laceration; pelvic hematoma; obstetric injury to the pelvic organs, pelvic joints or ligaments; injury to the bladder or urethra; and other pelvic trauma. Neonatal trauma included intracranial hemorrhage and laceration, skull fracture, severe injury to the central nervous system (e.g., cerebral edema, brain damage, injury to the cranial nerves, spine or spinal cord) or to the peripheral nervous system (e.g., Erb paralysis, brachial plexus injury, Klumpke paralysis), fracture of the long bones, injury to the liver or spleen, seizures, neonatal death) (Appendix 1, Table S1).

\section{Statistical analysis}

We stratified deliveries by mode of delivery using an intentionto-treat framework. For example, we included cesarean delivery after a failed forceps attempt in the attempted forceps delivery group. We calculated crude rates of maternal and neonatal trauma among spontaneous vaginal deliveries and OVDs to provide context. We did not make any direct comparisons between trauma rates following OVD and spontaneous vaginal deliveries since confounding by indication compromises such contrasts. However, we estimated adjusted incidence rate ratios (IRRs), adjusted number needed to treat and 95\% confidence intervals (CIs) using log-binomial regression for outcomes among forceps versus vacuum deliveries. Adjusted models included maternal province or territory of residence, age, parity, hypertension, diabetes, fetal distress during labour, pelvic station (i.e., outlet, low, midpelvic), ${ }^{13}$ post-term gestation ( $\geq 42$ weeks), and fetal macrosomia ( $\geq 4000 \mathrm{~g}$ ). We included missing values for parity $(7.0 \%)$ and for pelvic station $(7.7 \%$ for forceps, $34.8 \%$ for vacuum) in the multivariable models using a "missing" category.

We further compared rates of trauma related to OVD by region (i.e., province or territory) and by level of obstetric care. We stabilized trauma rates to account for the imprecision introduced by units with small numbers by grouping data from the 3 territories into a "combined territories" category and by using mixed-effects logistic regression..$^{28}$ The regression models included the same covariates listed above as fixed effects (to adjust risk for case mix) and a random intercept term, specific to the unit of comparison (i.e., province or territory, level of obstetric care). Additionally, we estimated the relationship between the OVD rate and trauma rates for each province or territory by year using the coefficient of determination $\left(R^{2}\right)$.

We evaluated outcome rates across tiers of service by province. Level of obstetric care in Canadian hospitals is designated by tier, ranging from tier 0 to tier 3 or 4 , which reflects the availability of increasing complexity of care. Tier of service classifications are province- and territory-specific. ${ }^{29,30}$ We excluded hospitals in tiers 0 and 1 since OVD is uncommon or not supported in such institutions. For simplicity, we conducted this analysis for only British Columbia, Alberta and Ontario.

Lastly, we quantified the association between volume of OVD at the hospital level and rates of trauma, while adjusting for the same covariates, using ecologic Poisson regression. ${ }^{31}$ Each hospital-year represented 1 unit of analysis (e.g., hospital A in 2013, hospital B in 2014). We evaluated the possibility of a nonlinear relationship between hospital OVD volume and the frequency of maternal trauma following OVD using a nonparametric model, smoothed using restricted cubic splines with 5 knots. ${ }^{32}$ We tested for nonlinearity using the likelihood ratio test and compared the linear and smoothed models.

\section{Ethics approval}

We obtained ethics approval for the study from the University of British Columbia (H17-00587). 


\section{Results}

We included 1326191 singleton deliveries at $\geq 37$ weeks' gestation in pregnant people without a previous cesarean delivery. Of these, 38500 (2.9\%) were attempted forceps deliveries and 110987 (8.4\%) were attempted vacuum deliveries (Figure 1). These deliveries resulted in 1236037 live births without congenital malformations (Appendix 2, Figure S1, available at www.cmaj. ca/lookup/doi/10.1503/cmaj.210841/tab-related-content). Forceps and vacuum deliveries were more frequent among nullip- arous than parous people, and in deliveries with fetal distress. Vacuum was more commonly used than forceps at all pelvic stations (Table 1). Of the 38500 attempted forceps deliveries, 1606 (4.2\%) failed, and 8791 (7.9\%) of the 110987 attempted vacuum deliveries failed (Appendix 1, Table S3).

\section{Maternal trauma}

Maternal trauma occurred in more than one-quarter of deliveries with forceps ( $n=9728,25.27 \%, 95 \% \mathrm{Cl} 24.83 \%$ to $25.70 \%$ ) (Table 2) and 14614 (13.17\%, 95\% Cl 12.97\% to $13.37 \%$ ) vacuum

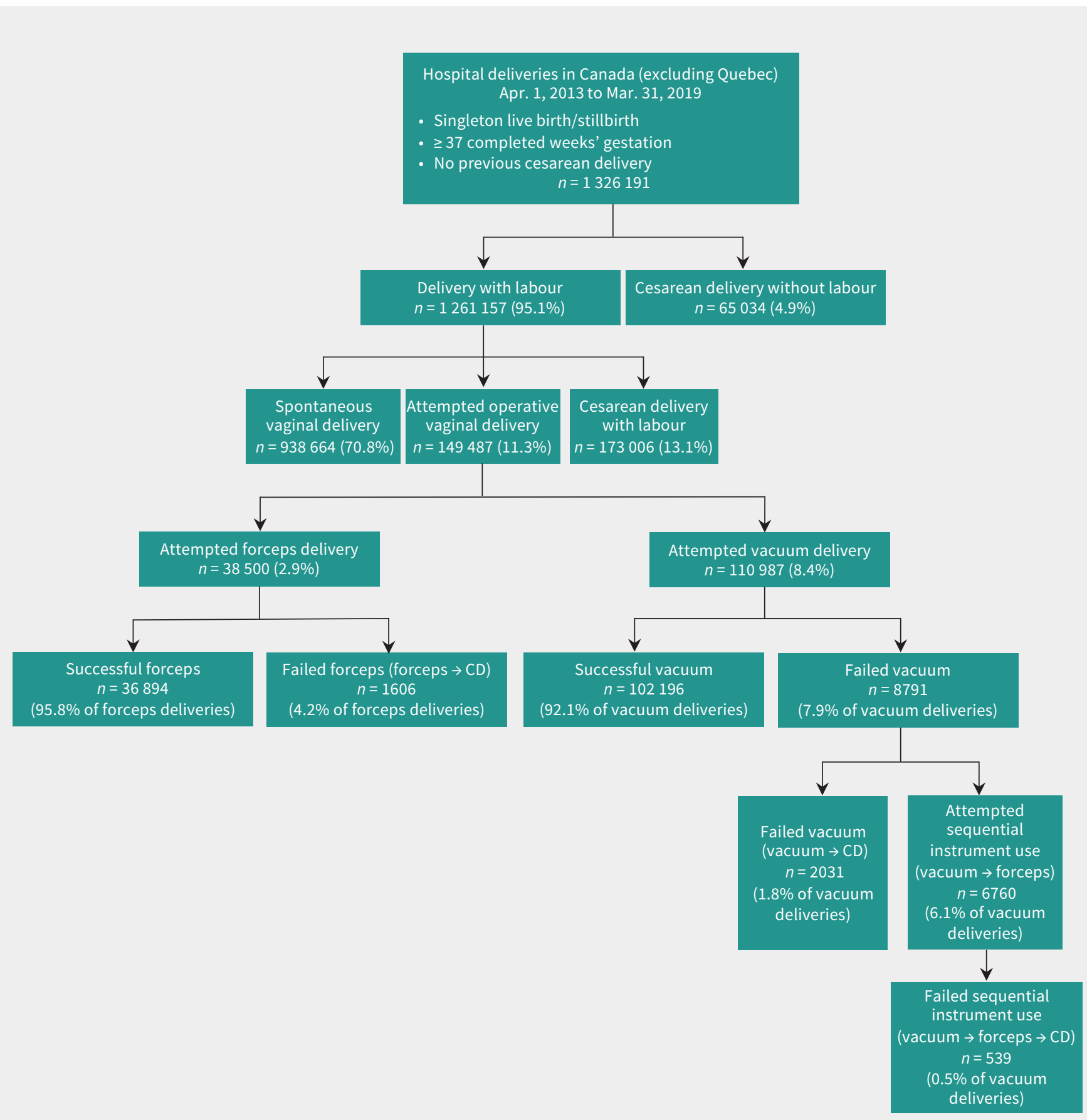

Figure 1: Distribution of deliveries included in the study by mode of delivery. Note: $C D=$ cesarean delivery. 
Table 1: Maternal, delivery and neonatal characteristics by mode of delivery in pregnant people without a previous cesarean delivery

\begin{tabular}{|c|c|c|c|c|c|}
\hline \multirow[b]{2}{*}{ Characteristic* } & \multirow{2}{*}{$\begin{array}{l}\text { Total no. of } \\
\text { deliveries }\end{array}$} & \multicolumn{4}{|c|}{ No. (\%) of deliveries } \\
\hline & & Spontaneous vaginal & Attempted forceps & Attempted vacuum & Cesarean \\
\hline All deliveries & 1326191 & $938664(70.8)$ & 38500 (2.9) & $110987(8.4)$ & 238040 (17.9) \\
\hline \multicolumn{6}{|l|}{ Maternal age, yr } \\
\hline$<20$ & 40646 & $30248(74.4)$ & $830(2.0)$ & $4004(9.9)$ & $5564(13.7)$ \\
\hline $20-24$ & 175889 & $130928(74.4)$ & $3932(2.2)$ & $14680(8.3)$ & $26349(15.0)$ \\
\hline $25-29$ & 390642 & $278521(71.3)$ & 11979 (3.1) & $34233(8.8)$ & 65909 (16.9) \\
\hline $30-34$ & 463558 & $325754(70.3)$ & 14578 (3.1) & $38648(8.3)$ & $84578(18.2)$ \\
\hline$\geq 35$ & 255444 & $173210(67.8)$ & $7180(2.8)$ & $19421(7.6)$ & $55633(21.8)$ \\
\hline \multicolumn{6}{|l|}{ Parity } \\
\hline 0 & 614482 & $330793(53.8)$ & $31151(5.1)$ & $75963(12.4)$ & $176575(28.7)$ \\
\hline 1 & 373915 & 323296 (86.5) & $3233(0.9)$ & $19751(5.3)$ & $27635(7.4)$ \\
\hline $2-3$ & 204421 & 183793 (89.9) & $922(0.5)$ & $7206(3.5)$ & $12500(6.1)$ \\
\hline$\geq 4$ & 40945 & $37093(90.6)$ & $116(0.3)$ & $1080(2.6)$ & $2656(6.5)$ \\
\hline Missing & 92428 & $63689(68.9)$ & $3078(3.3)$ & $6987(7.6)$ & $18674(20.2)$ \\
\hline \multicolumn{6}{|l|}{ Hypertension in pregnancy } \\
\hline Yes & 80690 & $46677(57.8)$ & $2826(3.5)$ & $7010(8.7)$ & $24177(30.0)$ \\
\hline No & 1245501 & 891987 (71.6) & 35674 (2.9) & $103977(8.3)$ & $213863(17.2)$ \\
\hline \multicolumn{6}{|l|}{ Pre-existing diabetes } \\
\hline Yes & 7273 & $3640(50.0)$ & $216(3.0)$ & $515(7.1)$ & $2902(39.9)$ \\
\hline No & 1318918 & 935024 (70.9) & 38284 (2.9) & $110472(8.4)$ & $235138(17.8)$ \\
\hline \multicolumn{6}{|l|}{ Gestational diabetes } \\
\hline Yes & 96734 & $62521(64.6)$ & $2968(3.1)$ & $7730(8.0)$ & $23515(24.3)$ \\
\hline No & 1229457 & $876143(71.3)$ & 35532 (2.9) & $103257(8.4)$ & 214525 (17.4) \\
\hline \multicolumn{6}{|l|}{ Fetal distress } \\
\hline Yes & 400584 & $182741(45.6)$ & $25641(6.4)$ & $78142(19.5)$ & $114060(28.5)$ \\
\hline No & 925607 & 755923 (81.7) & $12859(1.4)$ & 32845 (3.5) & $123980(13.4)$ \\
\hline \multicolumn{6}{|l|}{ Pelvic station $†$} \\
\hline Outlet & 17215 & - & $2316(13.5)$ & $14899(86.5)$ & - \\
\hline Low & 65594 & - & $22319(34.0)$ & $43275(66.0)$ & - \\
\hline Midpelvic & 25057 & - & $10884(43.4)$ & $14173(56.6)$ & - \\
\hline Unknown & 41621 & - & $2981(7.2)$ & $38640(92.8)$ & - \\
\hline \multicolumn{6}{|l|}{ Birth weight, gf } \\
\hline$\geq 4500$ & 12657 & 7459 (58.9) & $292(2.3)$ & $712(5.6)$ & $4194(33.1)$ \\
\hline $4000-4499$ & 31435 & $21745(69.2)$ & $934(3.0)$ & $2370(7.5)$ & $6386(20.3)$ \\
\hline$<4000$ & 1282099 & 909460 (70.9) & 37274 (2.9) & $107905(8.4)$ & $227460(17.7)$ \\
\hline \multicolumn{6}{|l|}{ Post-term delivery ( $\geq 42 \mathrm{wk}$ ) } \\
\hline Yes & 5213 & $2847(54.6)$ & $193(3.7)$ & $446(8.6)$ & $1727(33.1)$ \\
\hline No & 1320978 & 935817 (70.8) & 38307 (2.9) & $110541(8.4)$ & $236313(17.9)$ \\
\hline \multicolumn{6}{|l|}{ Province or territory } \\
\hline British Columbia & 193798 & $126807(65.4)$ & $7979(4.1)$ & $13867(7.2)$ & $45145(23.3)$ \\
\hline Alberta & 239684 & $164894(68.8)$ & $8926(3.7)$ & $22999(9.6)$ & $42865(17.9)$ \\
\hline Saskatchewan & 71626 & $50755(70.9)$ & $1745(2.4)$ & $8919(12.5)$ & $10207(14.3)$ \\
\hline Manitoba & 78947 & $61666(78.1)$ & $1194(1.5)$ & $5231(6.6)$ & $10856(13.8)$ \\
\hline Ontario & 638308 & $459214(71.9)$ & $16235(2.5)$ & $51467(8.1)$ & $111392(17.5)$ \\
\hline New Brunswick & 31143 & $22294(71.6)$ & $705(2.3)$ & $2908(9.3)$ & $5236(16.8)$ \\
\hline Nova Scotia & 38725 & $28192(72.8)$ & $1145(3.0)$ & $2783(7.2)$ & $6605(17.1)$ \\
\hline Prince Edward Island & 6197 & $4588(74.0)$ & $95(1.5)$ & $392(6.3)$ & $1122(18.1)$ \\
\hline Newfoundland \& Labrador & 20193 & $13964(69.2)$ & $444(2.2)$ & $1983(9.8)$ & $3802(18.8)$ \\
\hline Combined territories & 7570 & $6290(83.1)$ & $32(0.4)$ & $438(5.8)$ & 810 (10.7) \\
\hline
\end{tabular}

*People with missing values excluded (except for parity).

‡Restricted to live births without congenital anomalies (Appendix 2, Figure S1). 
deliveries (adjusted IRR $1.70,95 \% \mathrm{Cl} 1.65$ to 1.75 ). The frequency of OASI was particularly high with forceps delivery $(21.52 \% \mathrm{v}$. $11.67 \%$ with vacuum) and accounted for most of the maternal trauma with forceps and vacuum. The rate of fourth-degree perineal laceration was $2.20 \%$ with forceps and $1.22 \%$ with vacuum.

\section{Neonatal trauma}

The rate of neonatal trauma was similar for forceps (9.56 per 1000 live births, $95 \% \mathrm{Cl} 8.58$ to 10.62 ) and vacuum delivery (9.58 per 1000 live births, $95 \% \mathrm{Cl} 8.99$ to 10.18 ) (Table 2). Severe injury to the peripheral nervous system, the most frequent neonatal

Table 2: Maternal trauma and neonatal trauma among pregnant people with a spontaneous vaginal delivery, attempted forceps delivery or attempted vacuum delivery

\begin{tabular}{|c|c|c|c|c|c|c|c|c|c|c|}
\hline \multirow[b]{2}{*}{ Outcome } & \multicolumn{2}{|c|}{$\begin{array}{l}\text { Spontaneous } \\
\text { delivery }\end{array}$} & \multicolumn{2}{|c|}{$\begin{array}{c}\text { Attempted forceps } \\
\text { delivery }\end{array}$} & \multicolumn{2}{|c|}{$\begin{array}{c}\text { Attempted vacuum } \\
\text { delivery }\end{array}$} & \multicolumn{4}{|c|}{ Attempted forceps v. attempted vacuum $\dagger$} \\
\hline & $n$ & Rate* $^{\star}$ & $n$ & Rate* $^{\star}$ & $n$ & Rate* $^{\star}$ & ARR & $95 \% \mathrm{Cl}$ & NNT‡ & $95 \% \mathrm{Cl}$ \\
\hline All deliveries & 938664 & & 38500 & & 110987 & & & & & \\
\hline Maternal trauma & 32366 & 3.45 & 9728 & 25.27 & 14614 & 13.17 & 1.70 & 1.65 to 1.75 & 11 & 10 to 12 \\
\hline $\begin{array}{l}\text { Obstetric anal } \\
\text { sphincter injury }\end{array}$ & 26238 & 2.80 & 8285 & 21.52 & 12948 & 11.67 & 1.66 & 1.61 to 1.70 & 13 & 12 to 14 \\
\hline $\begin{array}{l}\text { Third-degree } \\
\text { perineal tear }\end{array}$ & 24015 & 2.56 & 7346 & 19.08 & 11457 & 10.32 & 1.64 & 1.59 to 1.69 & 15 & 14 to 16 \\
\hline $\begin{array}{l}\text { Fourth-degree } \\
\text { perineal tear }\end{array}$ & 2069 & 0.22 & 848 & 2.20 & 1354 & 1.22 & 1.78 & 1.62 to 1.97 & 103 & 83 to 129 \\
\hline $\begin{array}{l}\text { Unspecified } \\
\text { third- or fourth- } \\
\text { degree tear }\end{array}$ & 154 & 0.02 & 93 & 0.24 & 140 & 0.13 & 1.98 & 1.46 to 2.68 & 785 & 458 to 1672 \\
\hline Cervical tear & 1753 & 0.19 & 208 & 0.54 & 388 & 0.35 & 1.33 & 1.08 to 1.63 & 918 & 481 to 3788 \\
\hline $\begin{array}{l}\text { High vaginal } \\
\text { laceration }\end{array}$ & 1863 & 0.20 & 1193 & 3.10 & 1036 & 0.93 & 2.51 & 2.28 to 2.75 & 71 & 61 to 83 \\
\hline $\begin{array}{l}\text { Other pelvic } \\
\text { trauma }\end{array}$ & 2986 & 0.32 & 454 & 1.18 & 615 & 0.55 & 1.94 & 1.66 to 2.27 & 231 & 171 to 329 \\
\hline $\begin{array}{l}\text { Repair of urethra or } \\
\text { bladder }\end{array}$ & 300 & 0.03 & 20 & 0.05 & 45 & 0.04 & $1.24 \S$ & 0.69 to 2.22 & - & - \\
\hline All live births* & 880532 & & 35663 & & 103000 & & - & - & - & - \\
\hline Neonatal trauma & 1657 & 1.88 & 341 & 9.56 & 987 & 9.58 & 0.94 & 0.82 to 1.09 & - & - \\
\hline $\begin{array}{l}\text { Intracranial } \\
\text { hemorrhage }\end{array}$ & 25 & 0.03 & 25 & 0.70 & 85 & 0.83 & 0.76 & 0.44 to 1.33 & - & - \\
\hline Skull fracture & 6 & 0.01 & 24 & 0.67 & 27 & 0.26 & $2.41 \S$ & 1.29 to 4.49 & 3224 & 1302 to 15674 \\
\hline $\begin{array}{l}\text { Subgaleal } \\
\text { hemorrhage }\end{array}$ & 31 & 0.04 & 33 & 0.92 & 254 & 2.47 & 0.28 & 0.19 to 0.42 & -652 & -810 to -580 \\
\hline $\begin{array}{l}\text { Central nervous } \\
\text { system injury }\end{array}$ & 44 & 0.05 & 41 & 1.15 & 276 & 2.68 & 0.33 & 0.23 to 0.48 & -643 & -829 to -560 \\
\hline $\begin{array}{l}\text { Peripheral nervous } \\
\text { system injury }\end{array}$ & 837 & 0.95 & 173 & 4.85 & 351 & 3.41 & 1.33 & 1.08 to 1.65 & 873 & 443 to 3602 \\
\hline Erb paralysis & 323 & 0.37 & 71 & 1.99 & 120 & 1.17 & 1.80 & 1.27 to 2.55 & 1050 & 542 to 3112 \\
\hline $\begin{array}{l}\text { Other brachial } \\
\text { plexus injury }\end{array}$ & 516 & 0.59 & 107 & 3.00 & 237 & 2.30 & 1.15 & 0.88 to 1.50 & - & - \\
\hline $\begin{array}{l}\text { Injury to the long } \\
\text { bones }\end{array}$ & 228 & 0.26 & 22 & 0.62 & 108 & 1.05 & 0.77 & 0.46 to 1.28 & - & - \\
\hline Seizures & 520 & 0.59 & 73 & 2.05 & 170 & 1.65 & 1.32 & 0.94 to 1.84 & - & - \\
\hline Neonatal death & 41 & 0.05 & 11 & 0.31 & 31 & 0.30 & $1.10 \S$ & 0.51 to 2.37 & - & - \\
\hline \multicolumn{11}{|c|}{$\begin{array}{l}\text { Note: } \mathrm{ARR} \text { = adjusted rate ratio, } \mathrm{Cl}=\text { confidence interval, NNT = number needed to treat. } \\
{ }^{*} \text { Rates of maternal trauma are per } 100 \text { deliveries. Rates of neonatal trauma are per } 1000 \text { live births. Infants with congenital anomalies excluded. } \\
\text { †Adjusted models include maternal age, parity, maternal hypertension, maternal diabetes, fetal distress, post-term delivery, pelvic station of presenting part, macrosomic infant and } \\
\text { province or territory of maternal residence. }\end{array}$} \\
\hline
\end{tabular}


trauma, was more common following forceps $(4.85$ per 1000 live births, $95 \% \mathrm{Cl} 5.16$ to 5.63 ) than vacuum (3.41 per 1000 live births, $95 \% \mathrm{Cl} 3.06$ to 3.78 ) (adjusted IRR $1.33,95 \% \mathrm{Cl}$ 1.08 to 1.65$)$. Conversely, the rate of subgaleal hemorrhage was higher with vacuum (forceps v. vacuum adjusted IRR 0.28 , $95 \% \mathrm{Cl} 0.19$ to 0.42$)$. Absolute rates of neonatal trauma were low (Table 2).
Trauma rates by region

The crude rate of forceps delivery varied widely by region (from $0.4 \%$ to $4.1 \%$ ), a finding that remained after adjustment and stabilization (Appendix 1, Table S4). The adjusted rate of maternal trauma with forceps delivery also varied widely, from $17.7 \%$ to 41.0\% (Figure 2A; Appendix 1, Table S4). Adjusted rates of neonatal trauma following forceps delivery ranged from 0.0 to 10.3 per

A

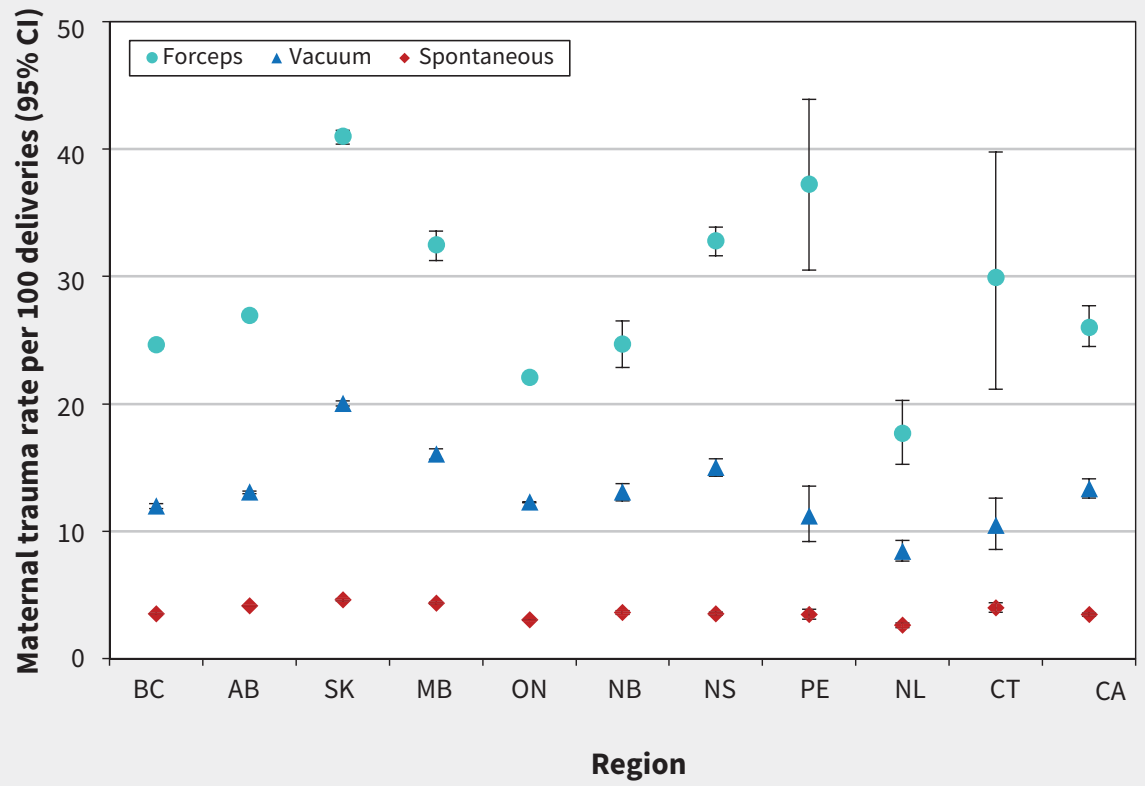

B

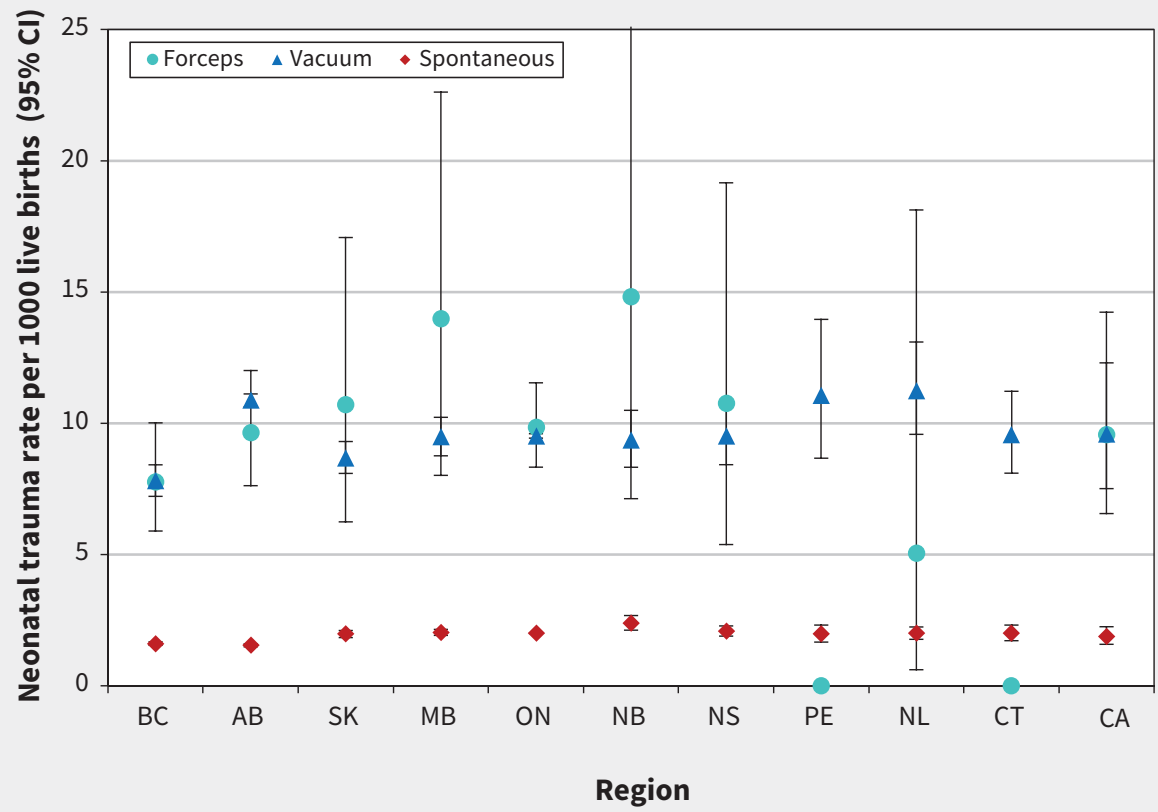

Figure 2: Rates of (A) maternal and (B) neonatal trauma following attempted forceps delivery, attempted vacuum delivery and spontaneous vaginal delivery, for all of Canada (CA), excluding Quebec, and stratified by province or territory (April 2013 to March 2019). We adjusted and stabilized rates using mixed-effects logistic regression. Note: $\mathrm{Cl}=$ confidence interval, $\mathrm{CT}=$ Combined territories. 
1000 live births; regions with nonzero rates did not vary significantly (Figure 2B). There was less regional variation in adjusted rates of vacuum delivery (6.7\% to 9.9\%; Appendix 1, Table S5), although adjusted rates of maternal trauma following vacuum delivery ranged from $8.4 \%$ to $20.0 \%$ (Figure $2 \mathrm{~A}$ ). Adjusted rates of neonatal trauma following vacuum delivery were similar across provinces (Figure 2B; Appendix 1, Table S5).

We observed a positive linear relationship between the OVD rate and the maternal trauma rate in a province or territory in a given year $\left(R^{2}=0.42, p<0.0001\right)$ but no association between OVD rate and neonatal trauma rate $\left(R^{2}=0.01, p=0.5\right.$; Appendix 2 , Figure S2).

\section{Trauma rates by level of care}

In British Columbia, Alberta and Ontario, the rates of maternal trauma were significantly higher with forceps than vacuum deliveries, and were similar across levels of obstetric care (Figure 3). Neonatal trauma rates were similar following forceps and vacuum delivery and did not vary with level of care (Appendix 2, Figure S3).

\section{Trauma rates by hospital OVD volume}

We included 1853 hospital-years in the ecologic Poisson regression. The adjusted rate of maternal trauma with forceps delivery decreased when hospital forceps use increased to 30 forceps deliveries per year (Figure 4A). We did not observe a relation between volume of forceps delivery and maternal trauma above this threshold, however, and most hospitals had average trauma rates of $23 \%-25 \%$. For vacuum deliveries, we observed a complex nonlinear relation in maternal trauma rates, with increasing vacuum use at low volume, but there was no relation between volume and trauma rate among hospitals performing more than about 200 vacuum deliveries per year, where the maternal trauma rate was $14 \%-16 \%$ (Figure 4B). The adjusted rate of neonatal trauma was not associated with hospital volume of OVD (Appendix 2, Figure S4).

\section{Discussion}

We evaluated the frequency of maternal and neonatal trauma following attempted forceps and attempted vacuum delivery in Canada (excluding Quebec), and stratified our analyses by region, level of obstetric care and hospital OVD volume. Maternal trauma rates were highest with forceps delivery, with more than 1 in 4 deliveries affected by maternal trauma and 1 in 105 infants affected by neonatal trauma. Maternal and neonatal trauma following vacuum deliveries occurred in 1 in 8 deliveries and 1 in 104 infants, respectively. Rates of OVD and maternal trauma following OVD varied substantially by region, with a positive correlation between the frequency of OVD use and maternal trauma. We did not observe any differences in trauma rates following OVD by level of obstetric care, nor was there a clear association between trauma and hospital volumes of OVD.

Despite rates of OVD similar to those in Canada, the rate of OASI following OVD is substantially lower in the UK $(8 \%-12 \%$ with forceps and $1 \%-4 \%$ with vacuum $)^{12}$ and in Australia (9.3\%-14.1\% with forceps and 5.4\%-5.9\% with vacuum; Table 3). ${ }^{14}$ The Organisation for Economic Co-operation and Development (OECD) reported that the 2015 rate of maternal trauma following OVD in Canada greatly exceeded that of any other OECD country (Appendix 2, Figure S5). ${ }^{33}$ Some of this variability is likely from differences in documentation and reporting, but clinician selection of patients, skill and choice of instrument are other potential causes. ${ }^{34}$ Variation in policy regarding the use of episiotomy in OVD may also be a factor. Accumulating evidence supports the routine use of mediolateral episiotomy in OVD, particularly among people having their first vaginal delivery, ${ }^{35-38}$ yet recommendations surrounding episiotomy in OVD are inconsistent across countries. The Royal Australian and New Zealand College of Obstetricians and Gynaecologists recommends use of routine episiotomy for all people having their first vaginal birth and requiring OVD, ${ }^{14}$ but restrictive use of mediolateral episiotomy in OVD is recommended in Canada. ${ }^{13}$ In a 2020 report from the UK, episiotomy was used in $90 \%$ of deliveries with forceps and $50 \%-60 \%$ of vacuum deliveries. ${ }^{12}$ Equivalent rates in Canada were $65 \%$ and $38 \%$, respectively, in 2018. ${ }^{35}$

In our study, OASI occured in $87 \%$ of deliveries with maternal trauma following OVD and accumulating evidence shows the severe long-term consequences of these injuries, ${ }^{39-44}$ such as urinary and fecal incontinence, dyspareunia and other pelvic floor disorders. ${ }^{39,40}$ Reported rates of anal incontinence following the primary repair of OASI are between $15 \%$ and $61 \%$ (mean $39 \%$ ), ${ }^{41,42}$ and these increase with time, from $31 \%$ at 3-6 months to $54 \%$ at $3-8$ years following delivery. ${ }^{43}$ The frequency of OASI found in our study ( $21.5 \%$ with forceps and $11.7 \%$ with vacuum), compared with those reported in current OVD guidelines $(4.0 \%-$ $6.6 \%$ of all vaginal births) (Table 3 ), highlights the importance of reporting timely, empirically derived measures of risk that reflect the risks pregnant people actually encounter in typical obstetric practice.

Morbidity following OVD needs to be compared with potential alternatives to OVD. These include an extended second stage of labour and a spontaneous vaginal delivery, or a second-stage cesarean delivery, both of which are associated with serious morbidity. ${ }^{5-7,45}$ However, the high population rates of morbidity following OVD also raise questions about the choice of instrument, obstetrician training in OVD use and the potential ability to recognize patients who would benefit from a cesarean delivery earlier in labour. In our study, rates of maternal trauma following OVD were high among all levels of obstetric care. Further study of optimal training environments is warranted.

\section{Limitations}

Some degree of misclassification in diagnoses and interventions recorded in large databases is inevitable. However, several studies have validated the information in the Discharge Abstract Database used in this study (Appendix 1, Table S2), ${ }^{25-27}$ and the data are abstracted by trained medical records personnel using standardized rules, with oversight by $\mathrm{CIHI}$. A related report ${ }^{46}$ on the safety of OVD in the 386 hospitals included in this study 
A

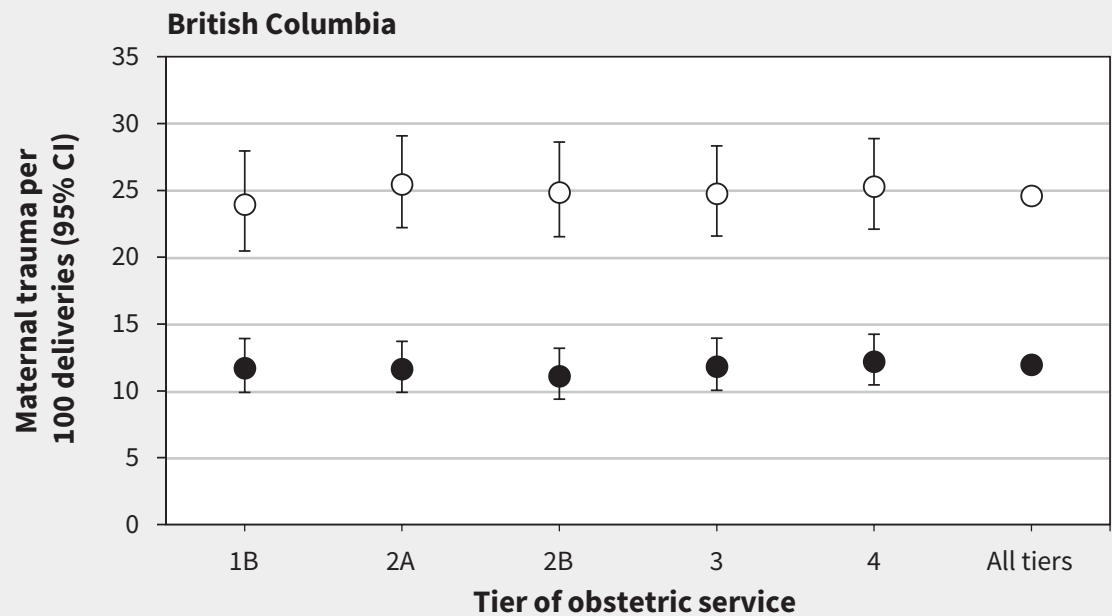

B

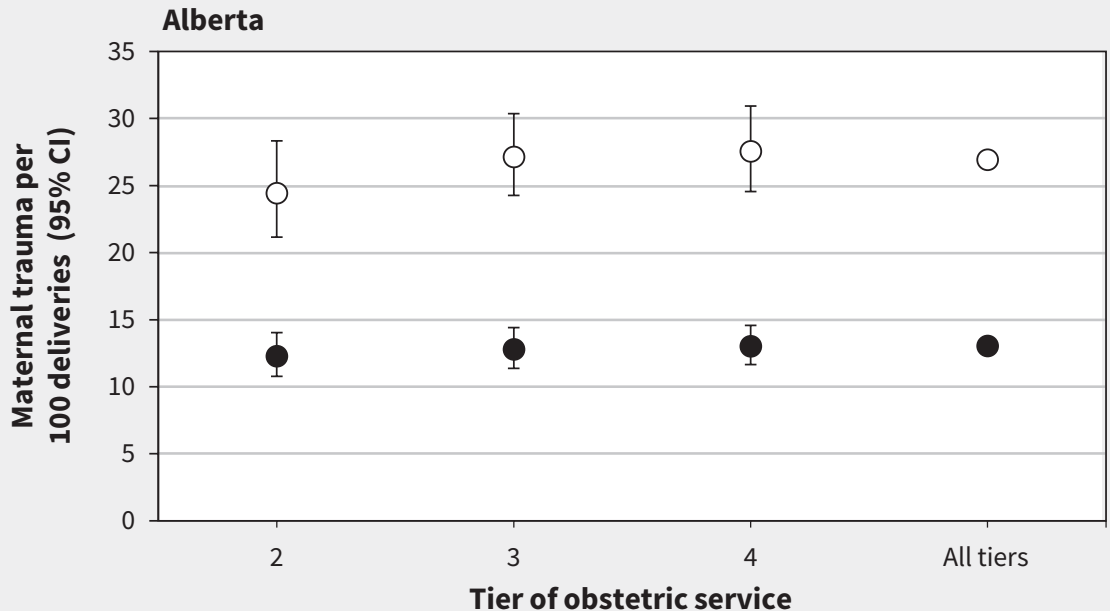

C

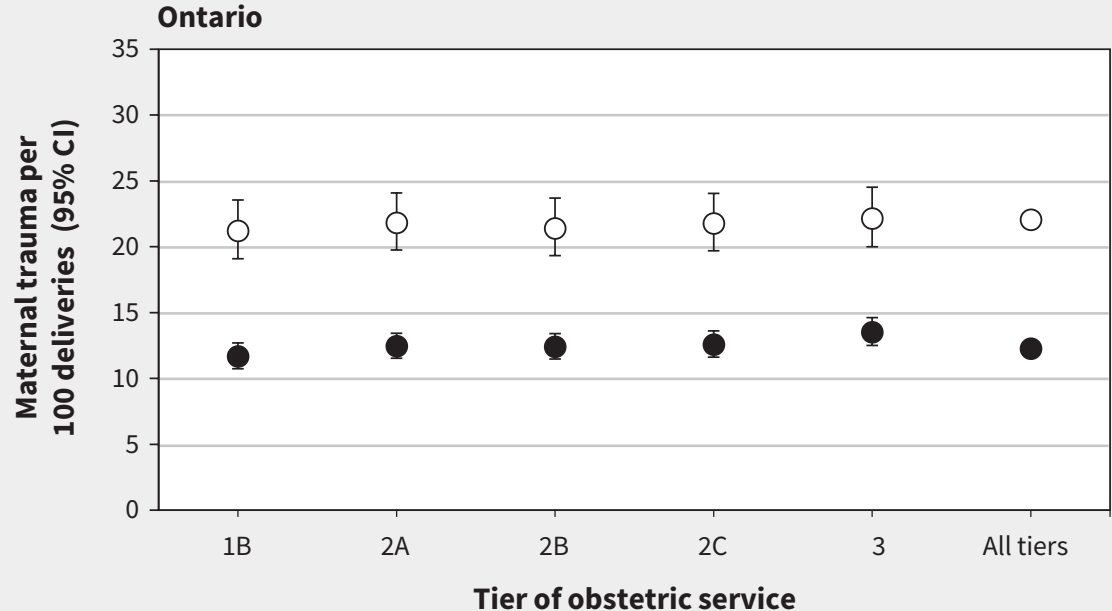

O Forceps deliveries

- Vacuum deliveries

Figure 3: Maternal trauma rates following attempted forceps and attempted vacuum delivery by tier of obstetric service in (A) British Columbia, (B) Alberta and (C) Ontario (April 2013 to March 2019). We adjusted and stabilized rates using mixed-effects logistic regression. Analysis by tier of service was province- or territory-specific, as these frameworks varied across jurisdictions. Numeric (e.g., Tier 1, Tier 2, Tier 3) or alphanumeric (Tier 1, Tier 2A, Tier 2B) labels are used to identify tiers of obstetric service with increasing complexity of care. ${ }^{29} \mathrm{Note}: \mathrm{Cl}=$ confidence interval. 
A
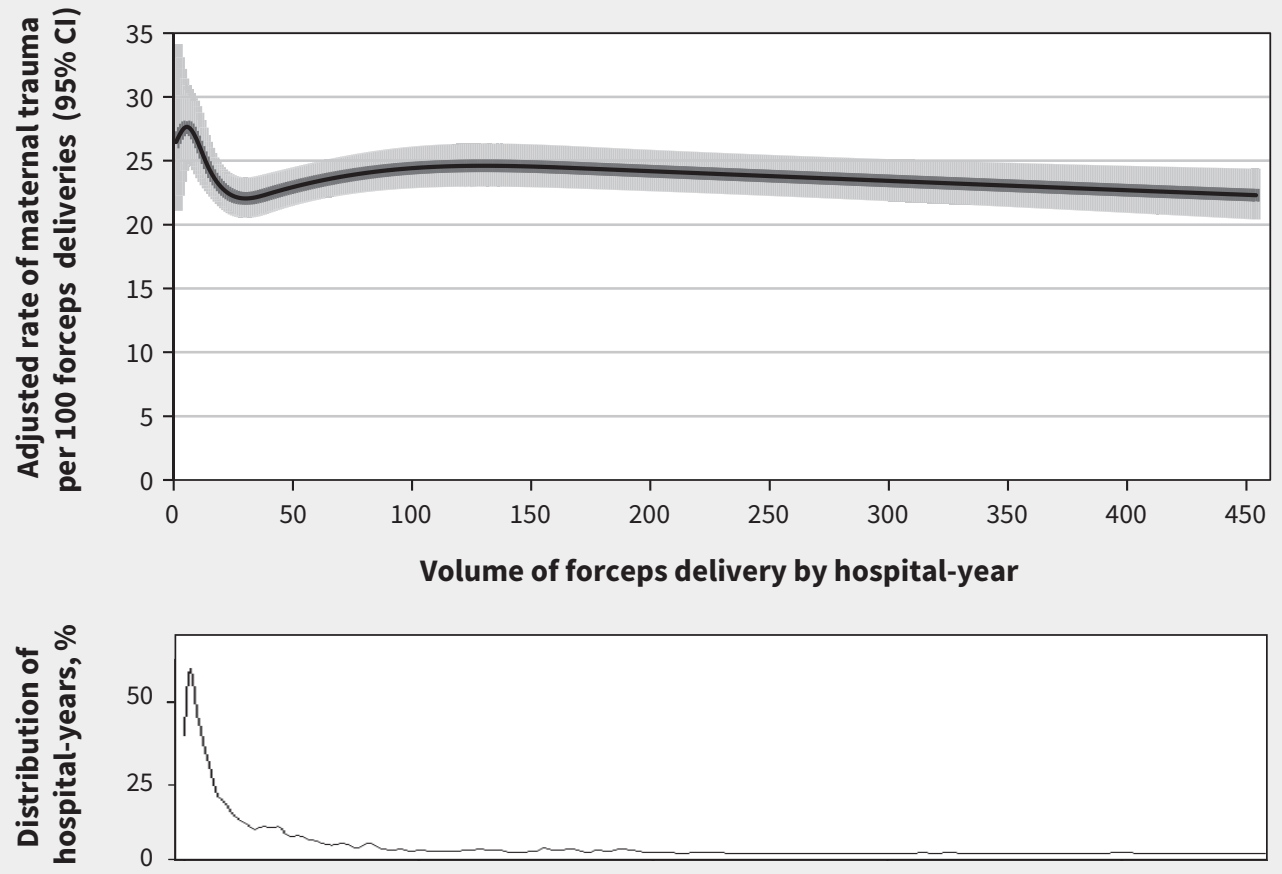

Volume of forceps delivery by hospital-year

B
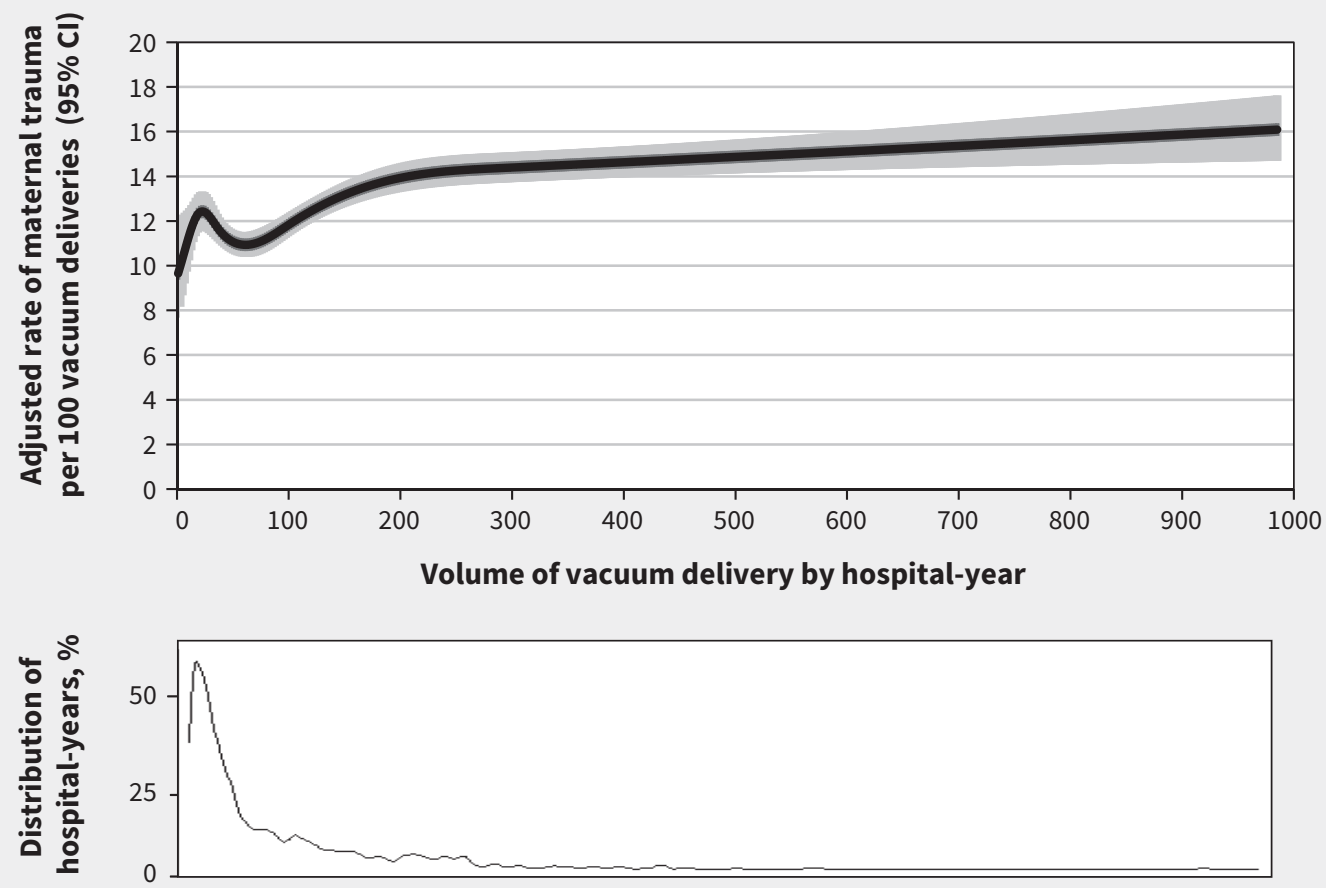

Volume of vacuum delivery by hospital-year

Figure 4: Rates of maternal trauma per 100 (A) forceps deliveries and (B) vacuum deliveries by the annual volume of forceps delivery in each hospital, and distribution of hospital-years by annual forceps volume (April 2013 to March 2019). We adjusted and stabilized rates using mixed-effects logistic regression. Note: $\mathrm{Cl}=$ confidence interval. 
Table 3: Incidence rates of maternal and neonatal trauma following operative vaginal delivery in the current study compared with those reported in OVD guidelines ${ }^{12-14}$

\begin{tabular}{|c|c|c|c|c|}
\hline \multirow[b]{2}{*}{ Outcome } & \multicolumn{4}{|c|}{ Incidence } \\
\hline & Current study & SOGC & RCOG & RANZCOG \\
\hline \multicolumn{5}{|l|}{ Maternal trauma } \\
\hline $\begin{array}{l}\text { OASI (third- and fourth- } \\
\text { degree perineal tear) }\end{array}$ & $\begin{array}{l}\text { F: } 21.5 \text { per } 100 \text { deliveries } \\
(1 \text { in } 4.7) \\
\text { V: } 11.7 \text { per } 100 \text { deliveries } \\
(1 \text { in } 8.6)\end{array}$ & $\begin{array}{l}\text { Between } 4.0 \% \text { and } 6.6 \% \\
\text { of all vaginal births }\end{array}$ & $\begin{array}{l}\text { F: } 8 \% \text { to } 12 \% \\
\text { V: } 1 \% \text { to } 4 \%\end{array}$ & $\begin{array}{l}\text { No incidence rate } \\
\text { provided. }\end{array}$ \\
\hline $\begin{array}{l}\text { Fourth degree perineal } \\
\text { tear }\end{array}$ & $\begin{array}{l}\mathrm{F}: 2.2 \text { per } 100 \text { deliveries } \\
(1 \text { in } 45) \\
\text { V: } 1.2 \text { per } 100 \text { deliveries } \\
(1 \text { in } 83)\end{array}$ & $\begin{array}{l}\text { No incidence rate } \\
\text { provided. }\end{array}$ & $\begin{array}{l}\text { No incidence rate } \\
\text { provided. }\end{array}$ & $\begin{array}{l}\text { No incidence rate } \\
\text { provided. }\end{array}$ \\
\hline \multicolumn{5}{|l|}{ Neonatal trauma } \\
\hline Intracranial hemorrhage & $\begin{array}{l}\text { F: } 0.70 \text { per } 1000 \text { births } \\
(1 \text { in } 1430) \\
\text { V: } 0.83 \text { per } 1000 \text { births } \\
(1 \text { in } 1205)\end{array}$ & $\begin{array}{l}F \& V: 1.16 \text { per } 1000 \\
\text { births ( } 1 \text { in } 860)\end{array}$ & $\begin{array}{l}\mathrm{F} \& \mathrm{~V}: 0.5 \text { to } 1.5 \text { per } 1000 \\
\text { (between } 1 \text { in } 2000 \text { and } 1 \\
\text { in 667) }\end{array}$ & $\begin{array}{l}\text { F: } 1.51 \text { per } 1000 \text { births } \\
(1 \text { in } 664) \\
\text { V: } 1.16 \text { per } 1000 \text { births } \\
(1 \text { in } 860)\end{array}$ \\
\hline Subgaleal hemorrhage & $\begin{array}{l}\text { F: } 0.92 \text { per } 1000 \text { births } \\
(1 \text { in } 1087) \\
\text { V: } 2.47 \text { per } 1000 \text { births } \\
(1 \text { in } 405)\end{array}$ & $\begin{array}{l}\text { V: } 1 \text { in } 1000 \text { deliveries } \\
\text { with a rigid plastic cup }\end{array}$ & $\begin{array}{l}\text { "Predominantly } \\
\text { vacuum", } 3.0 \text { to } 6.0 \text { per } \\
1000 \text { births } \\
\text { (between } 1 \text { in } 167 \text { and } 1 \\
\text { in 333) }\end{array}$ & V: 1 in 300 births \\
\hline Skull fracture & $\begin{array}{l}\text { F: } 0.67 \text { per } 1000 \text { births } \\
(1 \text { in } 1493) \\
\text { V: } 0.26 \text { per } 1000 \text { births } \\
(1 \text { in } 3846)\end{array}$ & $\begin{array}{l}\text { No incidence rate } \\
\text { provided. }\end{array}$ & $\begin{array}{l}\text { "Mainly forceps, rare" } \\
\text { No incidence rate } \\
\text { provided. }\end{array}$ & $\begin{array}{l}\text { No incidence rate } \\
\text { provided. }\end{array}$ \\
\hline Brachial plexus injury & $\begin{array}{l}\text { F: } 4.85 \text { per } 1000 \text { births } \\
(1 \text { in } 206) \\
\text { V: } 3.41 \text { per } 1000 \text { births } \\
(1 \text { in } 293)\end{array}$ & $\begin{array}{l}\text { F: } 5 \text { in every } 10000 \text { births } \\
(1 \text { in 2000)* }\end{array}$ & $\begin{array}{l}\text { No incidence rate } \\
\text { provided. }\end{array}$ & $\begin{array}{l}\text { No incidence rate } \\
\text { provided. }\end{array}$ \\
\hline Seizures & $\begin{array}{l}\text { F: } 2.05 \text { per } 1000 \text { births } \\
(1 \text { in } 488) \\
\text { V: } 1.65 \text { per } 1000 \text { births } \\
(1 \text { in } 606)\end{array}$ & $\begin{array}{l}\text { No incidence rate } \\
\text { provided. }\end{array}$ & $\begin{array}{l}\text { No incidence rate } \\
\text { provided. }\end{array}$ & $\begin{array}{l}\text { No incidence rate } \\
\text { provided. }\end{array}$ \\
\hline Neonatal death & $\begin{array}{l}\text { F: } 3.1 \text { per } 10000 \text { births } \\
(1 \text { in } 3226) \\
\text { V: } 3.0 \text { per } 10000 \text { births } \\
(1 \text { in } 3333)\end{array}$ & $\begin{array}{l}\text { No incidence rate } \\
\text { provided. }\end{array}$ & $\begin{array}{l}\text { No incidence rate } \\
\text { provided. }\end{array}$ & $\begin{array}{l}\text { No incidence rate } \\
\text { provided. }\end{array}$ \\
\hline
\end{tabular}

Note: $\mathrm{F}=$ forceps, OASI = obstetric anal sphincter injury, RANZCOG = The Royal Australian and New Zealand College of Obstetricians and Gynaecologists, RCOG = Royal College of Obstetricians and Gynaecologists (United Kingdom), SOGC = Society for Obstetricians and Gynaecologists of Canada, V= vacuum.

${ }^{\star}$ Rate misreferenced and miscalculated.

showed large variations among hospitals in the type of instrument used and trauma rates, suggesting major differences among hospitals in obstetric practice (including indication for use and skill of obstetrician). Although measurement of pelvic station can be subjective and affected by moulding and fetal head position, ${ }^{47}$ our data reflect the current norms of diagnosis by contemporary maternity care providers in Canada. We lacked information on the pregnant person's predisposition to trauma (e.g., family history of pelvic floor dysfunction), body mass index, multiple deliveries, rotational or nonrotational OVD, and the class of third-degree perineal laceration, which limits a more nuanced understanding of variations in trauma rates.

\section{Conclusion}

Rates of maternal and neonatal trauma following OVD are high in Canada compared with other countries with similar rates of OVD, and are especially high in some provinces. These high rates call for a reassessment of the safety of OVD, not just in Canada, but in all settings where the rates of OVD and the opportunities for training in OVD are changing. Although OVDs may be associated with low rates of morbidity in carefully selected circumstances, the high rates of trauma following forceps and vacuum deliveries, documented across regions, levels of obstetric care and hospitals, show that such ideal conditions do not apply to obstetric practice in Canada. 


\section{References}

1. Cunningham, FG, Leveno, KJ, Bloom, SL, et al. Williams obstetrics. 25th ed. New York: McGraw-Hill Medical; 2018.

2. Bahl R, Murphy DJ, Strachan B. Decision-making in operative vaginal delivery: when to intervene, where to deliver and which instrument to use? Qualitative analysis of expert clinical practice. Eur J Obstet Gynecol Reprod Biol 2013;170: 333-40.

3. Caughey AB, Cahill AG, Guise JM, et al. Safe prevention of the primary cesarean delivery. Am J Obstet Gynecol 2014;210:179-93.

4. Murphy DJ. Operative vaginal delivery. Best Pract Res Clin Obstet Gynaecol 2019; $56: 1-2$.

5. Murphy DJ, Liebling RE, Verity L, et al. Early maternal and neonatal morbidity associated with operative delivery in second stage of labour: a cohort study. Lancet 2001;358:1203-7.

6. Muraca GM, Sabr Y, Lisonkova S, et al. Morbidity and mortality associated with forceps and vacuum delivery at outlet, low and midpelvic station. J Obstet Gynaecol Can 2019;41:327-37.

7. Muraca GM, Skoll A, Lisonkova S, et al. Perinatal and maternal morbidity and mortality among term singletons following midcavity operative vaginal delivery versus caesarean delivery. BJOG 2018;125:693-702.

8. Halscott TL, Reddy UM, Landy HJ, et al. Maternal and neonatal outcomes by attempted mode of operative delivery from a low station in the second stage of labor. Obstet Gynecol 2015;126:1265-72.

9. Bailit JL, Grobman WA, Rice MM, et al. Evaluation of delivery options for second-stage events. Am J Obstet Gynecol 2016;214:638.e1-638.e10.

10. Muraca GM, Sabr Y, Brant R, et al. Temporal and regional variations in operative vaginal delivery in Canada by pelvic station, 2004-2012. J Obstet Gynaecol Can 2016;38:627-35.

11. National perinatal data collection. Perinatal data visualisations: method of delivery. Canberra (AU): Australian Institute of Health and Welfare; updated 2021 June 28. Available: https://www.aihw.gov.au/reports/mothers-babies/ australias-mothers-babies-data-visualisations/contents/labour-and-birth/method -of-birth (accessed 2020 Oct. 3).

12. Murphy DJ, Strachan BK, Bahl R; Royal College of Obstetricians Gynaecologists. Assisted vaginal birth. BJOG 2020;127:e70-112.

13. Hobson S, Cassell K, Windrim R, et al. No. 381 - assisted vaginal birth. J Obstet Gynaecol Can 2019;41:870-82.

14. Instrumental vaginal birth. Victoria (AU): Royal Australian and New Zealand College of Obstetrician and Gynaecologists (RANZCOG); 2020. Available: https://ranzcog.edu.au/statements-guidelines/obstetrics/instrumental-vaginal -birth-(c-obs-16) (accessed 2020 Oct. 3).

15. Loudon JA, Groom KM, Hinkson L, et al. Changing trends in operative delivery performed at full dilatation over a 10-year period. J Obstet Gynaecol 2010;30:370-5.

16. Merriam AA, Ananth CV, Wright JD, et al. Trends in operative vaginal delivery, 2005-2013: a population-based study. BJOG 2017;124:1365-72.

17. Daly JO, de Leeuw JW, Harvey MA, et al. Regarding SOGC guideline no. $381-$ assisted vaginal birth. J Obstet Gynaecol Can 2020;42:405-6.

18. Dietz HP, Esegbona G. Green-top guideline no. 26 "assisted vaginal birth". BJOG 2020;127:1581. doi: 10.1111/1471-0528.16422.

19. Hull PM, Thomas K, Skinner E, et al. Re: Assisted vaginal birth: Green-top guideline no. 26. Montgomery is missing from RCOG's Assisted Vaginal Birth guideline BJOG 2020;127:1297-8.

20. Pairaudeau N. The end of forceps delivery? CMAJ 2017;189:E1097.

21. Barrett JFR, Zaltz A, Geary M, et al. Beware selection bias. CMAJ 2017;189:E1096.

22. Wen SW, Liu S, Marcoux S, et al. Uses and limitations of routine hospital admission/separation records for perinatal surveillance. Chronic Dis Can 1997;18:113-9.

23. International statistical classification of diseases and related health problems. Tenth revision-Canadian version. Ottawa: Canadian Institute for Health Information; 2015.

24. Canadian classification of health interventions. Ottawa: Canadian Institute for Health Information; 2015.

25. Joseph KS, Fahey J. Validation of perinatal data in the Discharge Abstract Database of the Canadian Institute for Health Information. Chronic Dis Can 2009;29:96-100.
26. Frosst G, Hutcheon J, Joseph KS, et al. Validating the British Columbia Perinatal Data Registry: a chart re-abstraction study. BMC Pregnancy Childbirth 2015;15:123.

27. Data quality study of the 2015-2016 Discharge Abstract Database: a focus on hospital harm. Ottawa: Canadian Institute of Health Information (CIHI); 2016.

28. Ash, AS, Normand, ST, Stukel, TA, et al.; Committee of Presidents of Statistical Societies (COPSS). Statistical issues in assessing hospital performance. Baltimore: Centers for Medicare \& Medicaid Services; revised 2012. Available: http://www.cms.gov/Medicare/Quality-Initiatives-Patient-Assessment-Instruments /HospitalQualitylnits/Downloads/Statistical-Issues-in-Assessing-Hospital -Performance.pdf (accessed 2021 Jan. 16).

29. Summary of the tiers of obstetric and neonatal service in Canadian hospitals. Report of the CIHR Team on Improving Perinatal Health Care Regionalization. Vancouver; 2020. Available: https://med-fom-phsr-obgyn.sites.olt.ubc.ca/ files/2021/03/TOSSummaryJune2020.pdf (accessed 2021 Sept. 15).

30. Standardized maternal and newborn levels of care definitions. Toronto: Provincial Council for Maternal and Child Health; 2013. Available: https://www.pcmch.on.ca/ wp-content/uploads/2015/07/Level-of-Care-Guidelines-2011-Updated-August1 -20131.pdf (accessed 2020 Sept. 8).

31. Morgenstern, H. Ecologic studies. In: Rothman KJ, Greenland S, Lash TL, editors. Modern epidemiology. 3rd ed. Philadelphia: Lippincott, Williams \& Wilkins; 2008:514-7.

32. Durrleman S, Simon R. Flexible regression models with cubic splines. Stat Med 1989;8:551-61.

33. Obstetric trauma. In: Health at a Glance 2017: OECD indicators. Paris: Organisation for Economic Co-operation and Development (OECD); 2017. doi: https://doi.org/10.1787/health_glance-2017-38-en (accessed 2020 Aug. 28).

34. Macfarlane AJ, Blondel B, Mohangoo A, et al. Wide differences in mode of delivery within Europe: risk-stratified analyses of aggregated routine data from the Euro-Peristat study. BJOG 2016;123:559-68.

35. Muraca GM, Liu S, Sabr Y, et al. Episiotomy use among vaginal deliveries and the association with anal sphincter injury: a population-based retrospective cohort study. CMAJ 2019;191:E1149-58.

36. de Leeuw JW, de Wit C, Kuijken JP, et al. Mediolateral episiotomy reduces the risk for anal sphincter injury during operative vaginal delivery. BJOG 2008; 115:104-8.

37. Sultan AH, Thakar R, Ismail KM, et al. The role of mediolateral episiotomy during operative vaginal delivery. Eur J Obstet Gynecol Reprod Biol 2019;240:192-6.

38. Frenette P, Crawford S, Schulz J, et al. Impact of episiotomy during operative vaginal delivery on obstetrical anal sphincter injuries. J Obstet Gynaecol Can 2019;41:1734-41.

39. Handa VL, Danielsen BH, Gilbert WM. Obstetric anal sphincter lacerations. Obstet Gynecol 2001;98:225-30.

40. Sultan, AH, Kettle, C. Diagnosis of perineal trauma. In: Sultan AH, Thakar R, Fenner DE, editors. Perineal and anal sphincter trauma: diagnosis and clinical management. London (UK): Springer-Verlag;2007:13-9.

41. Harvey MA, Pierce M, Walter JE, et al. Obstetrical anal sphincter injuries (OASIS): prevention, recognition, and repair. J Obstet Gynaecol Can 2015;37:1131-48.

42. Sultan, AH, Thakar, R. Third- and fourth-degree tears. In: Sultan AH, Thakar R, Fenner DE, editors. Perineal and anal sphincter trauma: diagnosis and clinical management. London (UK): Springer-Verlag;2007:33-51.

43. Wegnelius G, Hammarstrom M. Complete rupture of anal sphincter in primiparas: long-term effects and subsequent delivery. Acta Obstet Gynecol Scand 2011;90:258-63.

44. Nilsson IEK, Åkervall S, Molin M, et al. Symptoms of fecal incontinence two decades after no, one, or two obstetrical anal sphincter injuries. Am J Obstet Gynecol 2021;224:276.e1-23.

45. Murphy DJ, Liebling RE, Patel R, et al. Cohort study of operative delivery in the second stage of labour and standard of obstetric care. BJOG 2003;110:610-5.

46. Muraca, GM, Boutin, A, Cherian, AM, et al. Attempted forceps and attempted vacuum delivery: maternal and neonatal trauma rates by province/territories, tier of obstetric service and hospital, Canada, April 2013 to March 2019. Report of the CIHR Team for Improving Perinatal Health Care Regionalization. Vancouver; 2021. Available: https://phsr.obgyn.ubc.ca/operative-vaginal-delivery/ (accessed 2021 Dec. 13).

47. Dupuis $\mathrm{O}$, Silveira R, Zentner A, et al. Birth simulator: reliability of transvaginal assessment of fetal head station as defined by the American College of Obstetricians and Gynecologists classification. Am J Obstet Gynecol 2005;192:868-74. 
Competing interests: Michael Kramer reports funding from the Canadian Institutes of Health Research and the Family Rosenquist Foundation, outside the submitted work. He also reports participation on the data safety monitoring board of the MOBYDick clinical trial and on the scientific advisory board of the Family Rosenquist Foundation.

This article has been peer reviewed.

Affiliations: Department of Obstetrics and Gynaecology (Muraca, Boutin, Lisonkova, John, Joseph), University of British Columbia, Vancouver, BC; Clinical Epidemiology Unit, Department of Medicine (Muraca, Razaz), Solna, Karolinska University Hospital, Karolinska Institutet, Stockholm, Sweden; Department of Pediatrics (Boutin), Université Laval, Québec City, Quebec; School of Population and Public Health (Lisonkova, Joseph); Division of Neonatology, Department of Pediatrics (Ting), University of British Columbia, Vancouver, BC; Department of Obstetrics and Gynaecology (Scott), Dalhousie University and the IWK Health Centre, Halifax, NS; Departments of Epidemiology and Occupation Health and of Pediatrics (Kramer), McGill University, Montréal, Que.
Contributors: Giulia Muraca and KS Joseph proposed the study concept and design, and conducted the analyses. Amélie Boutin, Neda Razaz, Sarka Lisonkova, Sid John, Joseph Ting, Heather Scott and Michael Kramer interpreted the data. Giulia Muraca drafted the manuscript. All the authors reviewed the manuscript critically for intellectual content, gave final approval of the version to be published and agreed to be accountable for all aspects of the work.

Content licence: This is an Open Access article distributed in accordance with the terms of the Creative Commons Attribution (CC BY-NC-ND 4.0) licence, which permits use, distribution and reproduction in any medium, provided that the original publication is properly cited, the use is noncommercial (i.e., research or educational use), and no modifications or adaptations are made. See: https://creativecommons. org/licenses/by-nc-nd/4.0/

Funding: Giulia Muraca is supported by a Canadian Institutes of Health Research (CIHR) Postdoctoral Fellowship. Amélie Boutin is supported by a Killam Postdoctoral Research Fellowship Award and a Fellowship Award from CIHR. Neda Razaz is supported by the Swedish Research Council for Health, Working Life and
Welfare (DNR 4-2707/2019). Sarah Lisonkova is supported by a Scholar Award from the Michael Smith Foundation for Health Research. KS Joseph is supported by an Investigator award from the BC Children's Hospital Research Institute. This study was funded by a Canadian Institutes of Health Research Team grant (PER-150902) on perinatal care regionalization in Canada.

Data sharing: These data were acquired from the Canadian Institute for Health Information (CIHI). Access to these data is available to researchers, health managers and decisionmakers via a formal data request process administered by $\mathrm{CIHI}$. More information on the data holdings and the request process is available at: www.cihi.ca/en/access-data-and -reports/make-a-data-request.

Acknowledgement: The authors would like to acknowledge the contribution of the members of the Canadian Institutes of Health Research Team on Regionalized Perinatal Health Care. A list of team members and affiliations can be found at https://phsr.obgyn.ubc.ca/members/

Accepted: Sept. 27, 2021

Correspondence to: Giulia Muraca, giulia.muraca@ki.se 